\title{
Interference in Solving Mathematical Problems
}

\author{
Muhammad $\operatorname{Irfan}^{1}$, Cholis Sa'dijah², Naufal Ishartono ${ }^{3}$, Sri Adi Widodo ${ }^{4}$, Arief Aulia \\ Rahman ${ }^{5}$, Muhammad Nur Hudha ${ }^{6}$ \\ \{muhammad.irfan@ustjogja.ac.id ${ }^{1}$, cholis.sadijah.fmipa@um.ac.id²,ni160@ums.ac.id ${ }^{3}$ \} \\ Universitas Sarjanawiyata Tamansiswa ${ }^{1,4}$ \\ Universitas Negeri Malang 2,3 \\ Universitas Muhammadiyah Surakarta ${ }^{5}$ \\ Universitas Kanjuruan Malang 6
}

\begin{abstract}
Many mathematical topics taught in schools have similarities in the structure of the problem, and the material is taught closely. Students often make mistakes in determining the problem solving method so that the answer is wrong. This error occurs because of the mixing of two knowledge that is close together so that someone is wrong in recalling the knowledge that should be used. In information processing theory, the event can be called interference. This paper will discuss how interference occurs in students' thinking processes when they solve mathematical problems. Subjects in this study were fourth semester students at one of the private universities in Yogyakarta selected purposively. This study uses an explorative qualitative approach, where researchers try to explore the process of the occurrence of student interference in solving mathematical problems. The findings of this study are that students experience semantic interference when changing word problem to mathematical models and when interpreting the answers obtained. In addition, students also experience procedural interference when choosing strategies to solve problems, resulting in incorrect answers.
\end{abstract}

Keywords: interference, semantic, procedure

\section{Introduction}

The topic of the proportion taught at junior high school starts from the proportion of two quantities, direct proportion, and inverse proportion. Each of these topics has keywords and characteristics that distinguish each type of proportion. In general, proportion is written in form of $\frac{a}{b}=\frac{c}{d}$ where a and $\mathrm{c}$ are the values of a variable, $\mathrm{b}$ and $\mathrm{d}$ are the values of other variables [1]-[3]. In addition to this form, a proportion can also be presented in the form of $y=m . x, m \neq 0$ [4]. Because the presentation is diverse, many students have difficulty understanding the concept of proportion [5]. In addition, the difficulty of students in understanding the concept of proportion is that they relate the concepts of propositions in their daily lives such as: speed, measurement, congruence, geometry, trigonometry [6]-[8]. Many math teachers teach proportions only emphasize the procedure according to what is written in the book. Moreover, math books used in schools contain formal rules for solving problems. Correspondingly, in general teachers only teach proportions by applying cross-multiplication rules to solve proportion problems [6]. When students apply the procedures taught by the teacher, and find the answers, they don't necessarily understand what is written. The use of 
procedures will only help students to find answers, but not for understanding concepts [9]. An understanding of the concept of proportions is important for studying other mathematical concepts, such as: congruency, area and volume, measurement, trigonometry, and algebra [10], [11].

The complexity of the problem of proportion because in proportion can be associated with other material. But the problem is that students are unable to associate / establish connections between knowledge proportions and others [3], [12]. As a result, students have difficulty when they solve problems. Difficulties experienced by students in the matter of proportion are varied. The findings of previous studies show that students find it difficult to differentiate between proportion and non-proportion problems [13], [14]. Whereas other studies found that students solved the addition problem using the proportion method and used the addition method in the proportion problem [15]. In addition, students also have difficulties in resolving direct and inverse proportion problems [16], [17].

In the direct proportion and inverse proportion problems, both of them have characteristics and keywords that distinguish one another. It's just that students sometimes struggle when solving direct and inverse proportion problems. Difficulties experienced by students include: students have difficulty connecting two quantities, procedural errors, and difficulties in choosing the right strategy [18]. While the findings of other studies indicate that students do not understand the use of variables, students do not understand the use of formulas, students do not understand keywords on the problem, students do not understand the problem, students do not understand how to simplify the form of division, and do not interpret the relationship of proportions correctly [19].

The difficulties experienced by students are likely to occur because of the similarity in the structure of the problem between direct and inverse proportion. Because of the similarity of the structure of the problem, there is a possibility that students have difficulty distinguishing clearly the two problems. This is supported by the learning process in class which usually learns one type of proportion first and does not present all types of proportions together. As a result, when students are faced with inverse proportion problems, they solve with the concept of direct proportion, or vice versa. This disorder is called thinking interference.

Interference is one of the basic problems that a person has [20], [21]. Interference can cause someone to forget. Interference occurs when students have the construction of two or more different concepts in which two or more concepts are interrelated [22]. Interference is distinguished based on the time information is received, namely proactive interference and retroactive interference [21]. Proactive interference occurs when information that previously disturbed / damaged new information. While retrospective interference occurs when new information interferes / damages the previous information. Several other studies distinguish interference into two types, namely stimulus interference and response interference [23]. Stimulus interference is a disorder in which a person is unable to understand various information that is known, where various information is similar. Whereas response interference is a disturbance that arises when students respond / reaction to the problem at hand. In addition, there is also semantic interference, namely the meaning disturbance in the form of expansion and narrowing of meaning [24], [25]. 


\section{Research Method}

This study involved 120 students from the fourth semester Mathematics Education program, 2016/2017 academic year at Private Universities in the city of Yogyakarta. The student has taken education from elementary to high school, including vocational schools (with concentration: accounting, health, marketing, computer and network engineering, etc.). Thus, student input in the school year is very diverse and can be said to be in the second level. All students were given a matter of proportions, as in Table 1. Then, they worked on the question on the paper that had been provided for 20 minutes. After that, researchers examined their answers. The researcher separates the right answer and the wrong answer. From the student's work, the researcher chose the wrong answer because the researcher wanted to know the mistakes made by students when solving the problem. The researcher chooses the subject by considering several things, including: communication skills, unique answers, and suggestions from several lecturers. The uniqueness of the answers chosen by the researcher is the answers that use non-proportional methods to solve the problem of proportions, the use of unusual proportional relationships, and the incompatibility between the questions and the answers written. Based on these criteria, researchers obtained three research subjects. Of the three students, the researchers conducted interviews one by one to explore in-depth information related to their work. On average, researchers need about 20-30 minutes to interview a student. The goal is to find out why they are wrong in solving problems and why they use the strategies they choose. In the end, researchers can find out students' mistakes in solving the problem of proportion.

Table 1. Problem

\begin{tabular}{l}
\hline Question \\
\hline Mrs. Tumini needs 90 meatballs and $3 \mathrm{~kg}$ noodles to make 30 \\
portions of meatballs. How many meatballs and noodles are needed \\
to make 100 servings of meatballs?
\end{tabular}

\section{Result and Discussion}

\subsection{Result}

After examining the work of students, the researchers found that $85 \%$ of students were unable to answer correctly for questions A and 55\% for questions B. From these facts, it showed that students had difficulties in solving the problem of proportion. Uniquely, there are some students who use elimination and substitution to solve the problem of proportion. It is known that the method of elimination and substitution is often used to solve the problem of the system of linear equations (non-proportions). In fact, the question given by researchers is a matter of proportion. These findings are like the findings of previous studies which showed that students used non-standard methods (additive, affine, multiplication) to solve the problem of proportion [13]-[15], [26], [27]. Students use the elimination and substitution method because they assume that the two quantities in the problem are two variables. Because there are two variables, the problem is considered a matter of the two-variable linear equation system. So they use elimination and substitution methods. 
If this is seen from the information processing theory [28], [29] it can be said that when the subject is given an external stimulus in the form of a problem, the subject reads the problem and tries to understand it as the register stage and initial processing. Furthermore, the subject recalled the knowledge gained while studying at the junior high school level. Supposedly, the subject uses the concept of proportion but what happens is another thing that is the concept of the two-variable linear equation system that is called. If viewed based on time, the subject can be said to experience retroactive interference, because the material of proportion is taught first rather than the material of the two-variable linear equation system. However, if observed more deeply, the proportion of material was taught in grade VII of junior high school, while the material of linear equation system of two variables was taught in grade VIII of junior high school. So it will be difficult if students have to call it retroactive interference because the two materials are not close together. But if researchers look at different sides such as how to choose a problem solving strategy conducted by the subject, the subject chooses a strategy to use elimination and substitution rather than using proportions, then it can be said that the subject is experiencing procedural interference. Procedure interference is a disorder that occurs as a result of the mixing of two procedures that have similarities with one another (see Figure 1).

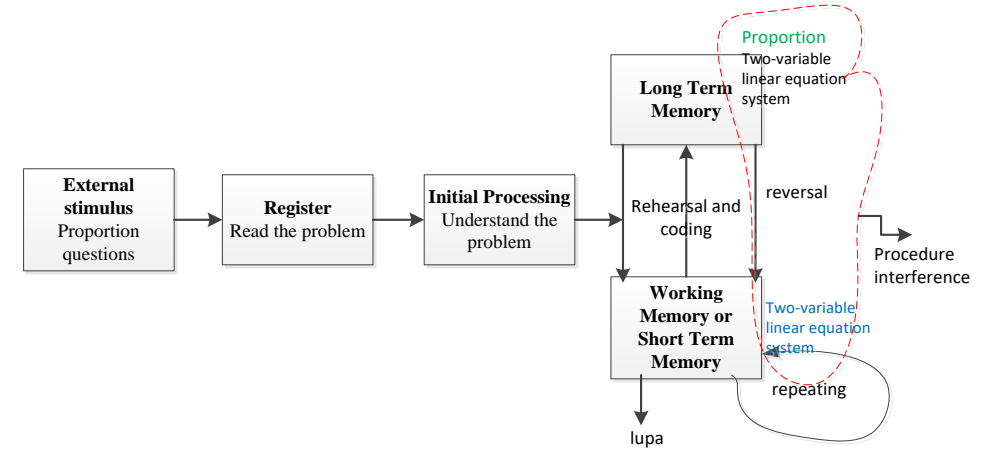

Figure 1. The Interference Procedure

In addition to procedure interference, the researcher also found that the subject was unable to change the sentence in the matter of being a mathematical model. In Figure 2, the subject writes $90 x+3 y=30 ; x+y=100$, where $x$ represents meatballs and y represents noodles. Does $x+y=100$ represent the sentence 'how many meatballs and noodles are needed to make 100 servings of meatballs?' If $x+y=100$ is changed to a sentence according to the context of the problem, then the meaning is' requires 1 noodle and 1 meatball to make 100 portion. 'This is the concern of the researcher. Another case is when the researcher gives a question to the seventh grade junior high school students, then the subject works as follows:

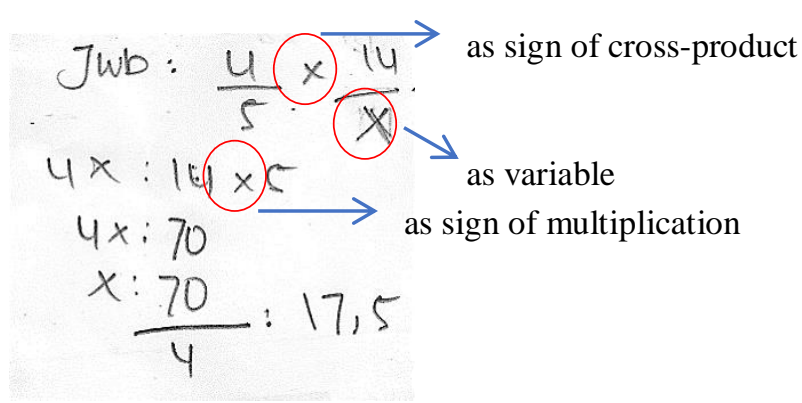


Figure 2. The work of Junior High School Students

From Figure 2, it can be seen that the subject uses the ' $x$ ' to represent three different things, namely: cross multiplication, variables, and multiplication. This means that the " $x$ " sign has three different meanings, whereas in the previous case, " $x+y=100 "$ is not a mathematical model of "how many meatballs and noodles are needed to make 100 servings of meatballs?" This results in multiple meanings and can cause disruption in understanding concepts and in solving problems. Conditions like this can be said to be semantic interference, namely interference that occurs because there is a change in meaning when the sentences in the problem are changed to a mathematical model or a sign / word that has more than one meaning that can damage / disturb.

\subsection{Discussion}

The problem of proportion is a complex problem and can be found in various conditions, such as: speed, making bread, measuring, making drinks [6]. This makes students have to think deeply to solve it. Usually, the problem of the proportion presented by teachers in schools is only the proportion of one thing (single proportion). Suppose Susi bought 2 notebooks for $\mathrm{Rp}$ $4,500.00$. How much money should Susi pay if she buys 7 notebooks? Of course this kind of problem is easily obtained. In this study, the researcher presents the problem of proportion with three quantities at once (multiple proportions), namely meatballs, noodles and servings.

According to Figure 3, the subject did not use the proportion method to solve the problem. $\mathrm{He}$ actually uses the method of elimination and substitution to solve the problem of proportion. This is a unique phenomenon, that students use non-proportional ways to solve the problem of proportion [13], [15]. From the subject's work, he obtained the answers $x=-3.1$ and $\mathrm{y}=103$ (see Figure 3). At the beginning of the work, the subject performs an example, namely by using the variable $\mathrm{x}$ for meatballs and the variable $\mathrm{y}$ for noodles. So, 90 meatballs and $3 \mathrm{~kg}$ noodles to make 30 servings of meatballs are changed to $90 x+3 y=30$, and the meatballs and noodles needed to make 100 portions of meatballs are changed to $x+y=100$. Then, from the existing equation, the system is formed of a linear equation system of two variables (LESTV). After using the elimination and substitution method $x=-3.1$ and $\mathrm{y}=103$ were found. According to him, the interpretation $x=-3.1$ and $y=103$ was to make 100 servings of meatballs requiring $-3,1$ meatballs and 103 noodles. From the interpretation of the answers obtained, it can be seen that the subject is merely answering the question by performing an imitation procedure [30]-[32]. He does not reflect on what he has done. Could meatballs amount to -3.1 ? 


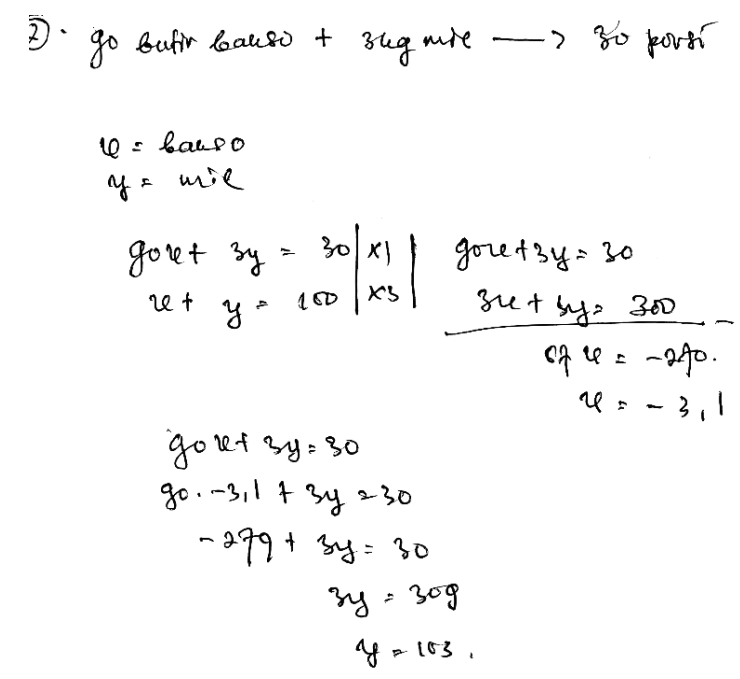

FIGURE 3. Subject 1 's Work

To dig further information, researchers conducted interviews with the subject about the answers to the questions given. The fragments of interviews conducted by the researcher can be seen as shown in Figure 4.

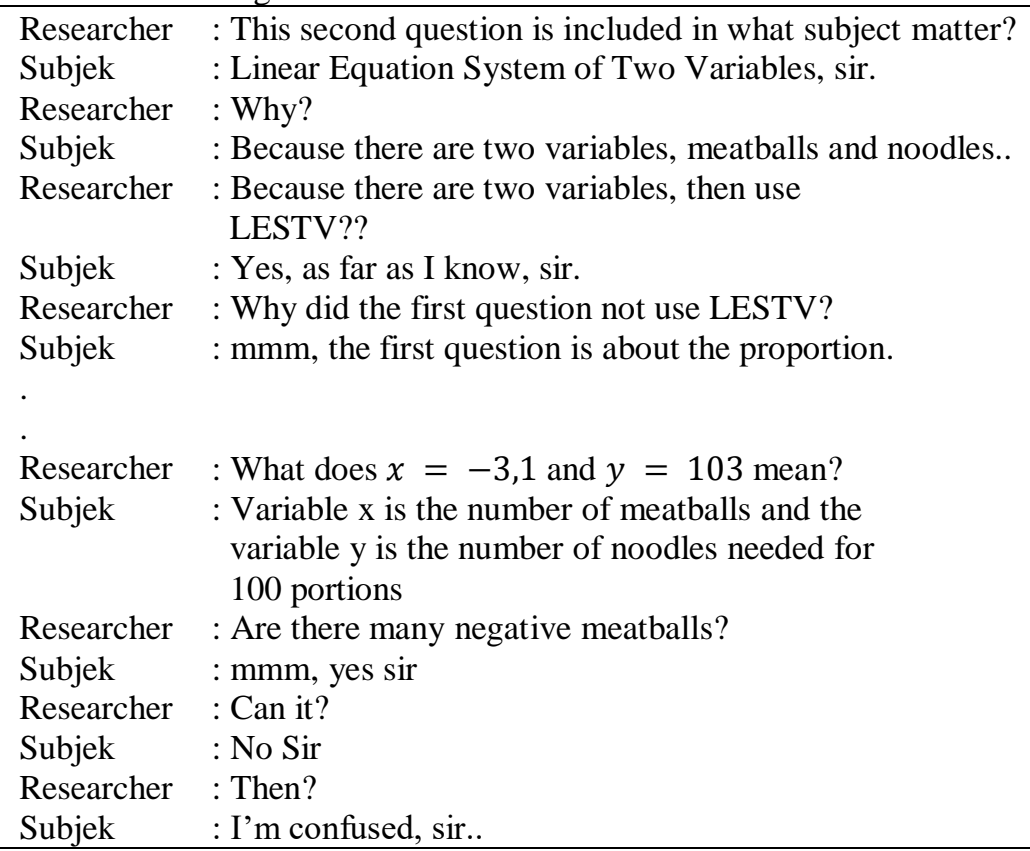

.FIGURE 4. The Interview of the Researcher with Subjek 1

From the interview in Figure 4, the subject understands the problem of proportion as a problem of Linear Equation System of Two Variables. He considers that meatballs and noodles are two variables so that in problem solving planning, subject 1 uses elimination and substitution methods to find the values of $\mathrm{x}$ and $\mathrm{y}$. After obtaining the values $x=-3.1$ and 
$\mathrm{y}=103$, subject 1 does not reflect his work. Are the values $x=-3.1$ and $\mathrm{y}=103$ fulfilling the existing equation? Could it be that $\mathrm{x}$ is negative? When the Researcher asks why $\mathrm{x}$ is negative, the subject cannot answer correctly.

In problem B, subject 2 worked on the given question as the method carried out by subject 1 was by elimination and substitution method. At that time, he used a two-variable linear equation system to answer questions. The difference between the two answers given by subject 1 and subject 2 was in the $\mathrm{x}$ value. Subject 1 got the value $x=-3.1$, while subject 2 obtained $\mathrm{x}$ value of $3.1 \approx 3$. If seen in Figure 4 , the work step written by subject 2 is $3 x+3 y=300-(90 x+3 y=30)$. Based on this step, he should get $-87 x=270$, and $x=-3.1$. This means that in addition to understanding the proportion that has not been good, subject 2 has an understanding of the operation of algebraic forms that are not good too. To understand the proportions, it is necessary to understand the fractions and algebraic reasoning well [33], [34].

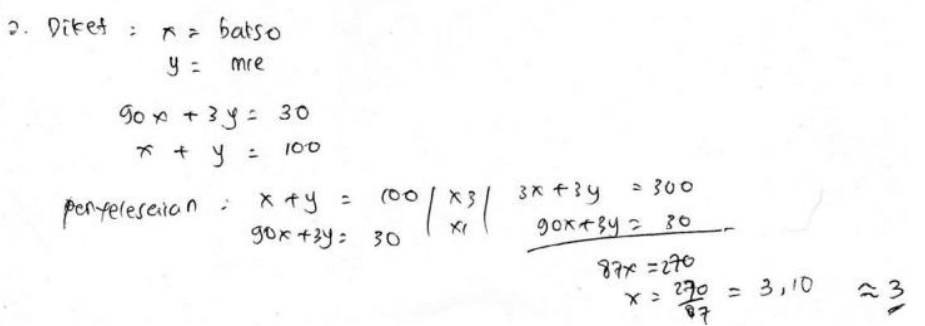

FIGURE 5. Subject 2's Work

Researcher conducts an interview with subject 2 about work on the second question. The fragment of the interview can be seen as in Figure 6.

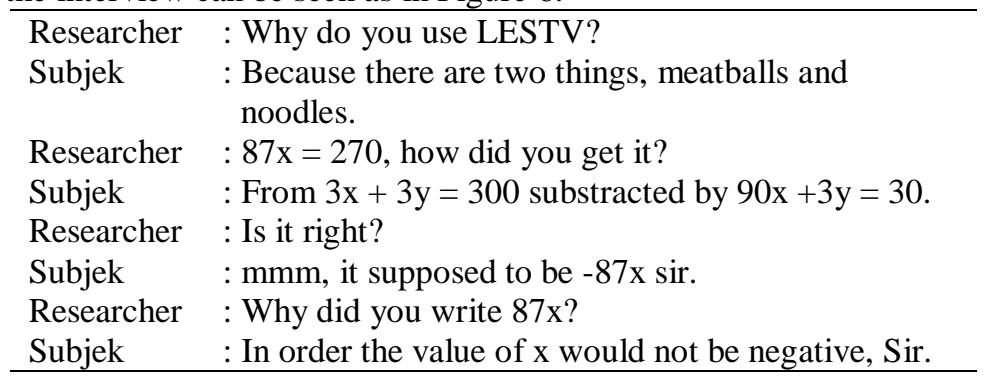

FIGURE 6. The Interview of the Researcher with Subjek 2

Subject 2 realized that he made a mistake when writing $87 x=270$. He wrote $87 x=270$ to avoid negative $\mathrm{x}$ values. He is aware that the value of $\mathrm{x}$ cannot be negative. However, he is like subject 1, using LESTV to solve the problem of proportions with two objects.

The problem of proportions is very closely related to problems in everyday life as described by [5], [35]. To understand the problem of proportions is not easy [36]. The problem of proportion is a complex problem and this problem is the basis for understanding the concept of algebra [37]. The complexity of the problems that occur in the topic of proportion because in the topic of proportion can be related to other material. The findings of this research support the previous research that found that many students were wrong in solving problems because they did not understand the problem and inaccuracy in choosing a problem solving strategy [13], [38]-[40]. In addition, the findings of this research are that students experience procedural interference and semantic interference when solving problems. Procedure 
interference is a disturbance that occurs due to the mixing of two procedures that have similarities with one another. While semantic interference occurs because there is a change in meaning when the sentence that is in the problem is converted into a mathematical model or one sign / word has more than one meaning that can be destructive / disturbing. Pre-service teachers are the next generation of teachers who will teach students at school. If the teacher has a superficial understanding of the concept of proportion, of course the student also experiences the same thing. Therefore, the pre-service teachers need to review the lessons in elementary, middle and high school.

\section{Conclusion}

Based on the results of data collection analysis, it can be concluded that students have different errors. Students have difficulties in solving unusual problems. This is a result of routine procedures and formal rules that are always used to solve the problem of proportion. Students experience difficulties in understanding problems, as a result, they are unable to solve problems correctly. They are not able to solve the problem because they only implement routine procedures taught by the teacher while in junior high school and math books. In addition, students also have difficulty in choosing a problem solving strategy. This happens because the structure of the problem given by the researcher is different from what is usually found in textbooks. In carrying out problem-solving strategies, students do not understand the relationship of the proportion that he is constructing. But by calculation, students are able to do it well. In addition, the subject is not able to interpret the results of the calculation into the problem. The subjects also did not reflect on their work, so they did not know whether the answers they produced were relevant or not.

Errors made by students in solving the problem of proportion are different. Although the number of subjects in this research is only two, this can describe the condition of students' proportional reasoning with characteristics such as this research. This needs to be a concern for lecturers and educational developers, especially those who are in direct contact with universities that get student input as in this research, so that they can help teachers and students to improve proportional reasoning. This research is the starting point for conducting research on disruption of proportional reasoning construction. Errors made by students can occur because of a failure to recall the knowledge they have because of interference. The findings of this research are expected to be used as a basis for developing a proportional reasoning handbook, in order to minimize errors and interference in constructing proportional reasoning. The heading should be treated as a $3^{\text {rd }}$ level heading and should not be assigned a number. 


\section{References}

[1] K. Beswick, "Make Your Own Paint Chart: a Realistic Context for Developing Proportional Reasoning with Ratios," Aust. Math. Teach., vol. 67, no. 1, pp. 6-12, 2011.

[2] T. W. Boyer, S. C. Levine, and J. Huttenlocher, "Development of Proportional Reasoning: Where Young Children Go Wrong,” Dev. Psychol., vol. 44, no. 5, pp. 1478-1490, 2008.

[3] L. Parish, "Facilitating the Development of Proportional Reasoning through Teaching Ratio," Math. Educ. Res. Gr. Australas., pp. 469-476, 2010.

[4] R. Karplus, S. Pulos, and E. K. Stage, "Early Adolescents' Proportional Reasoning on 'Rate' Problems," Educ. Stud. Math., vol. 14, no. 3, pp. 219-233, 1983.

[5] A. I. Silvestre and J. P. da Ponte, "Missing value and comparison problems:What pupils know before the teaching of proportion," Pna, vol. 6, no. 3, pp. 73-83, 2012.

[6] S. N. Sumarto, F. Van Galen, Zulkardi, and Darmawijoyo, "Proportional reasoning: How do the 4th graders use their intuitive understanding?,” Int. Educ. Stud., vol. 7, no. 1, pp. 69-80, 2014.

[7] R. Ekawati, F. L. Lin, and K. L. Yang, "Developing an Instrument for Measuring Teachers' Mathematics Content Knowledge on Ratio and Proportion: A Case of Indonesian Primary Teachers," Int. J. Sci. Math. Educ., vol. 13, no. 1, pp. 1-24, 2015.

[8] T. Degrande, L. Verschaffel, and W. Van Dooren, "Proportional word problem solving through a modeling lens: A half-empty or half-full glass?.," in In Posing and solving mathematical problems, Switzerland: Springer, Cham., 2016, pp. 209-229.

[9] F. van Galen and D. van Eerde, "Solving Problems with the Percentage Bar," Indones. Math. Soc. J. Math. Educ., vol. 4, no. 1, pp. 1-8, 2013.

[10] S. M. P. A. Fatimatul Khikmiyah, Agung Lukito, "Students' Modelling in Learning The Concept of Speed," IndoMS. J.M.E, vol. 3, no. 1, pp. 87-98, 2012.

[11] R. S. Utari, R. I. I. Putri, and Y. Hartono, "SUPPORTING 7 TH STUDENTS ' PROPORTIONAL REASONING USING," in The Third South East Asia Design/Development Research International Conference, 2015, pp. 344-352.

[12] S. Subanji, "Proses Berpikir Pseudo Siswa dalam Menyelesaikan Masalah Proporsi," J-TEQIP, vol. 4, no. 2, pp. 207-226, 2013.

[13] C. Fernández, S. Llinares, W. Van Dooren, D. De Bock, and L. Verschaffel, "The Development of Students use of Additive and Proportional Methods along Primary and Secondary School," Eur. J. Psychol. Educ., vol. 27, no. 3, pp. 421-438, 2012.

[14] M. Irfan, S. Sudirman, and R. Rahardi, "Characteristics of students in comparative problem solving,” J. Phys. Conf. Ser., vol. 948, pp. 1-11, 2018.

[15] W. Van Dooren, D. De Bock, M. Evers, and L. Verschaffel, "Students' Overuse of Proportionality on Missing-Value Problems: How Numbers May Students' Overuse of Proportionality on Missing-Value Problems: How Numbers May Change Solutions," J. Res. Math. Educ., vol. 40, no. 2, pp. 187-211, 2009.

[16] D. De Bock, W. Van Dooren, and L. Verschaffel, "Students' understanding of proportional, inverse proportional, and affine functions: two studies on the role of external representations," Int. J. Sci. Math. Educ., vol. 13, no. 1, p. 47-69., 2013.

[17] M. S. Pelen and P. . D. Artut, “Seventh Grade Students' Problem Solving Success Rates on Proportional Reasoning Problems Seventh Grade Students ' Problem Solving Suc cess Rates on Proportional Reasoning Problems," Int. J. Res. Educ. Sci., vol. 2, no. 1, pp. 30-34, 2016.

[18] G. Valverde and E. Castro, "Prospective Elementary School Teachers 'Proportional Reasoning," Pna, vol. 7, no. 2005, pp. 1-19, 2012.

[19] M. Irfan, T. Nusantara, S. Subanji, and Sisworo, "Why Did the Students Make Mistakes in Solving Direct and Inverse Proportion Problem?," Int. J. Insights Math. Teach., vol. 01, no. 1, pp. 25-34, 2018.

[20] M. C. Anderson and J. H. Neely, Interference and Inhibition in Memory Retrieval, no. March. 1996.

[21] M. C. Anderson, Rethinking interference theory: Executive control and the mechanisms of forgetting, vol. 49, no. 4. 2003.

[22] S. Subanji and A. M. Supratman, "The Pseudo-Covariational Reasoning Thought Processes in 
Constructing Graph Function of Reversible Event Dynamics Based on Assimilation and Accomodation Frameworks," Korean Soc. Math. Educ., vol. 19, no. 1, pp. 61-79, 2015.

[23] L. Cragg, "The development of stimulus and response interference control in midchildhood," Dev. Psychol., vol. 52, no. 2, pp. 242-252, 2016.

[24] I. Bloem and W. La Heij, "Semantic facilitation and semantic interference in word translation: Implications for models of lexical access in language production," J. Mem. Lang., vol. 48, no. 3, pp. 468-488, 2003.

[25] T. Wei and T. T. Schnur, "Long-term interference at the semantic level: Evidence from blocked-cyclic picture matching," J. Exp. Psychol. Learn. Mem. Cogn., vol. 42, no. 1, pp. 149$157,2016$.

[26] V. Frith and R. Prince, "Quantitative literacy of school leavers aspiring to higher education in South Africa," Pythagoras, vol. 37, no. 1, pp. 138-161, 2016.

[27] W. Van Dooren, D. De Bock, A. Hessels, D. Janssens, and L. Verschaffel, "Students' Overreliance on Proportionality: Evidence from Primary School Pupils Solving Arithmetic Word Problems," in International Group for the Psychology of Mathematics Education, 2004.

[28] R. E. Slavin, Educational Psychology: Theory and Practice, 8th ed. Boston: Pearson Education, Inc., 2006.

[29] J. R. Sternberg and K. Sternberg, “Cognitive Psychology,” Science (80-. )., p. 609, 2011.

[30] I. Bayazit, "Quality of the Tasks in the New Turkish Elementary Mathematics Textbooks: the Case of Proportional Reasoning," Int. J. Sci. Math. Educ., vol. 11, no. 3, pp. 651-682, 2013.

[31] B. Grobecker, "The Evolution of Proportional Structures in Children with and without Learning Differences," Learn. Disabil. Q., vol. 22, no. 3, pp. 192-211, 1999.

[32] D. Ben-chaim, J. T. Fey, W. M. Fitzgerald, and C. Benedetto, "Proportional reasoning among 7th grade students with different curricular experiences," Educ. Stud. Math., vol. 36, no. 3, pp. 247-273, 1998.

[33] K. M. Doyle, O. Dias, J. R. Kennis, B. Czarnocha, and W. Baker, "The Rational Number SubConstructs as a Foundation for Problem Solving," Adults Learn. Math. An Int. J., vol. 11, no. 1, pp. 21-42, 2015.

[34] F. Van Galen, E. Feijs, N. Figueiredo, K. Gavemeijer, E. Van Herpen, and R. Keijzer, Fractions, percentages, decimals and proportions. 2008.

[35] T. W. Boyer and S. C. Levine, "Child proportional scaling: Is $1 / 3=2 / 6=3 / 9=4 / 12$ ?," J. Exp. Child Psychol., vol. 111, no. 3, pp. 516-533, 2012.

[36] J. Lobato, A. B. Ellis, R. I. Charles, and R. M. Zbiek, Developing Essential Understanding of Ratios, Proportions, and Proportional Reasoning for Teaching Mathematics in Grades 6-8. 1906 Association Drive, Reston, VA 20191-1502: National Council of Teachers of Mathematics, 2010.

[37] A. J. Hackenberg and M. Y. Lee, "Relationships between students' fractional knowledge and equation writing,” J. Res. Math. Educ., vol. 46, no. 2, pp. 196-243, 2015.

[38] M. Irfan, "Analisis Kesalahan Siswa dalam Pemecahan Masalah Berdasarkan Kecemasan Belajar Matematika," Kreano, J. Mat. Kreat., vol. 8, no. 2, pp. 143-149, 2017.

[39] R. Setianingsih, C. Sa'jidah, A. R. As'ari, and M. Muksar, "Investigating Fifth- Grade Students ' Construction of Mathematical Knowledge through Classroom Discussion,' Int. Electron. J. Math. Educ., vol. 12, no. 4, pp. 383-396, 2017.

[40] M. Irfan, "Proses Berpikir Siswa yang Mengalami Math-Anxiety dalam Menyelesaikan Masalah Sistem Persamaan Dua Variabel," Kalamatika J. Pendidik. Mat., vol. 3, no. 1, pp. 27 $38,2018$. 